\title{
PARA ALÉM DA DICOTOMIA POLITEÍSMO $X$ CRISTIANISMO: UM ESTUDO DE CASO SOBRE A RELIGIÃO ROMANA EM LIVROS DIDÁTICOS BRASILEIROS
}

JORWAN GAMA DA COSTA JUNIOR ${ }^{1}$

Resumo: Ainda que de forma incipiente no Brasil, a religião romana tem sido tema de debate nos círculos de discussões sobre a Antiguidade. Tratase de um conceito com variadas possibilidades de interpretação e com uma multiplicidade de características. Sendo assim, este artigo objetiva, em um primeiro momento, apresentar a atualidade desta discussão assim como definir alguns aspectos básicos da religião romana à luz das discussões teóricas que envolvem a história dos conceitos. Em um segundo momento, busca-se identificar se estas características básicas definidas pela historiografia atual são aplicadas na escrita histórica dos livros didáticos brasileiros aqui analisados.

Palavras-chave: Religião Romana, Antiguidade, Livros didáticos, História dos conceitos.

\footnotetext{
1 Doutorando em História pelo PPGH-UNIRIO. Mestre em História Comparada pelo PPGHC-IH-UFRJ. Atualmente leciona em escolas do Ensino Básico das redes públicas e privadas de ensino do Rio de Janeiro.
}

Este artigo versa a respeito da construção da escrita histórica sobre a religião romana em exemplares de livros didáticos brasileiros. Busca-se, sobretudo, analisar a imagem da religião romana criada nas páginas de três exemplares de livros didáticos. Sua análise permitirá compreender se tal imagem está de acordo com as recentes produções historiográficas acadêmicas, se permite entrever os princípios dos instrumentos normativos que regem a educação nacional e, por fim, se permite ao aluno questionar e criticar o próprio mundo em que vive, abrindo caminho para uma sociedade na qual as diferentes práticas religiosas sejam reconhecidas e respeitadas. ${ }^{2}$ Assim, evidencia-se a pertinência, defendida nestas páginas, do estudo da Antiguidade nos dias atuais, associada, principalmente, ao estudo da história dos conceitos, uma vez que questiono se a religião romana apresentada nos exemplares aqui estudados é tratada conceitualmente. Para integrar o corpus documental desse artigo, foram selecionados três livros didáticos voltados para o

\footnotetext{
${ }^{2}$ Este trabalho, portanto, segue as preocupações de renomados pesquisadores do ensino de história, como Circe Bittencourt (2009).
} 
Ensino Médio e de grande circulação nas escolas do Rio de Janeiro. Todos os exemplares fizeram parte do Plano Nacional dos Livros Didáticos ${ }^{3}$ e estão à venda em grande parte das livrarias nacionais.

\section{A ATUALIDADE da História ANTIGA, ALTERIDADE E O USO DE CONCEITOS}

Nos últimos anos, as cidades brasileiras têm convivido com episódios constantes de intolerância religiosa, que muitas vezes são destaques nas páginas policiais dos principais jornais da cidade e, em outras tantas ocasiões, são apenas esquecidos ou sequer divulgados. A não percepção do outro enquanto um elemento cultural que faz parte de uma sociedade diversa pode ser associada a violências de todos os tipos, inclusive a religiosa. ${ }^{4}$

A situação apresentada acima é justamente o contrário do que pregam os instrumentos normativos que regem a educação nacional, quais sejam: a Constituição Federal de 1988; os Parâmetros Curriculares Nacionais do Ensino Médio; e a Lei de Diretrizes e Bases da Educação Nacional. Esses instrumentos são categóricos ao afirmarem que o processo de ensino e aprendizagem no Brasil deve pautar-se pela preocupação premente de formação de um cidadão ativo na sociedade brasileira que fosse capaz de identificar, valorizar e, sobretudo, respeitar as diferenças interpessoais nos campos político, cultural e religioso. ${ }^{5}$ Uma sociedade que

\footnotetext{
${ }^{3}$ Ressalto que este artigo foi escrito durante a divulgação dos livros aprovados pelo PNLD 2017. Importante frisar que os três exemplares não se configuram como elementos constantes no mesmo PNLD, tendo em vista os anos das edições analisadas. Também ressalto que o PNLD específico para o Ensino Médio é definido pela terminologia PNLEM, que utilizarei ao longo deste artigo.

${ }^{4}$ Recorro aos escritos de Stuart Hall (2005) e Marc Augé (1999) para quem a alteridade e a identidade de uma sociedade só podem ser entendidas em conjunto.

${ }^{5}$ Conforme pode ser visto nos Parâmetros Curriculares Nacionais para o Ensino Médio "Isso implica o reconhecimento das diferenças e imediatamente a aceitação delas, construindo-se uma relação de respeito e convivência, que rejeita toda forma de preconceito, discriminação e exclusão; e na valorização de si mesmo como sujeito responsável pela construção da Historia; no respeito às diferenças culturais, étnicas, religiosas, politicas, evitando-se qualquer tipo de discriminação" (BRASIL, PCNEM, 2000 p. 12)
}

respeite e conviva com as diferenças deveria ser tema transversal das disciplinas escolares, principalmente das ciências humanas e, em especial, da história enquanto disciplina.

No cenário imaginado pela legislação educacional, os grupamentos humanos deveriam ser representados como resultado de um processo que os levou à formação de suas especificidades políticas, culturais e religiosas. É justamente nesse último campo que este trabalho se aloca, tendo como mola propulsora deste artigo a questão: como é representada a religião romana em alguns exemplares de livros didáticos nacionais? Depreende-se, assim, que este trabalho engloba discussões a respeito do ensino de História Antiga no Brasil, a relação entre academia e as salas de aulas na educação básica e, por fim, a produção historiográfica dos livros didáticos.

Por muito tempo, os historiadores que estudavam a Antiguidade Clássica receberam a pecha de inertes e neutros dentro da produção historiográfica nacional, nas últimas décadas, contudo, o trabalho de grupos de pesquisa voltados para a Antiguidade tem se destacado tanto nacional quanto internacionalmente. ${ }^{6} \mathrm{~A}$ qualidade dos trabalhos desenvolvidos pelo LHIA-UFRJ e por outros centros de pesquisa universitários pode ser comprovada pelos constantes intercâmbios feitos com especialistas estrangeiros e com as publicações, cada vez mais profícuas, de revistas especializadas em Antiguidade. Sendo assim, nas últimas décadas o Brasil viu seu número de doutores especializados em Antiguidade aumentar consideravelmente. No entanto, seria possível perceber este desenvolvimento acadêmico nos livros didáticos de História?7 Diretamente associada a essa pergunta surgem outras duas: o estudo

"O livro "A busca do Antigo" (BELTRÃO, C. et al. 2011) conta com a contribuição de pesquisadores internacionais como José D’Encarnação e Lynette Micthell, o que demonstra a profunda ligação das pesquisas nacionais com centros de pesquisa europeus.

${ }^{7} \mathrm{O}$ baixo número de especialistas em Antiguidade foi um dos maiores obstáculos na correta elaboração de livros didáticos, conforme notou Gilvan Ventura da Silva (2001, p. 19-24). 
da Antiguidade, como apresentado nos exemplares aqui analisados, contribui para a formação de um aluno que consiga pensar criticamente o mundo atual? Seria a Antiguidade uma boa ferramenta para um estudo que pudesse desvelar as variadas possibilidades de se pensar e de se expressar no mundo atual? Ambas as questões são diretamente associadas ao ambiente da educação básica, uma vez que integram, a partir da Antiguidade, o conteúdo escolar com o mundo em que o estudante vive.

Segundo Lynette Mitchell (2011, p. 135), a Antiguidade nos permite estudar não apenas o que seria próximo de nós, mas justamente o oposto. A partir da alteridade, distante no tempo e no espaço, poderíamos criticar nossa própria identidade e os elementos que dela fazem parte, assim como elaborar questões que permitem uma melhor compreensão do nosso mundo atual. O uso moderno da Antiguidade, indicado por Mitchell, aponta para a necessidade de repensar e analisar os conceitos empregados para interpretá-la, uma vez que eles estão profundamente influenciados pelos contextos históricos sob os quais foram formados. Nesse sentido, o livro didático, segundo Pedro Paulo Funari (2004), seria de grande valia, pois faria a ponte entre academia e sala de aula, permitindo a problematização dos conceitos, afastando o risco do anacronismo na construção do conhecimento histórico escolar.

Necessário ressaltar que o livro didático não serve apenas como um mero transportador do conhecimento acadêmico para dentro da sala de aula. Ainda que ele tenha que estar em harmonia com as contribuições da academia, ele supera esse papel. Um livro didático deve ser o elemento que permite ao aluno construir um conhecimento e problematizar tanto o mundo em que vive quanto as fontes históricas com que se depara em seu cotidiano. ${ }^{8}$ Tanto na questão da construção de um conhecimento histórico que partisse de problematizações

\footnotetext{
${ }^{8}$ Circe Bittencourt (2015, p. 71 e 72 ) alerta para outras duas outras facetas do livro didático: enquanto uma mercadoria de grande valor no mercado editorial nacional e, sobretudo, como depositários dos conteúdos escolares.
}

para o questionamento do mundo em que vive, quanto na relação entre academia e sala de aula, a Antiguidade teria grande relevância, ainda mais se levada em consideração os aspectos traçados acima por Lynette Mitchell. Parto do conceito de República para exemplificar esta relação. Enquanto forma de governo do Brasil, alguns aspectos fundamentais de uma República já são conhecidos de um aluno do ensino médio, dentre os quais se encontra a eleição para cargos políticos. O termo, em si, já é conhecido pelo estudante, dando a ele a sensação de proximidade com a República Romana. ${ }^{9}$ Contudo, essa república apresenta idiossincrasias que as diferenciam do cotidiano republicano brasileiro com o qual o aluno está mais familiarizado. Portanto, a partir do conceito de República Romana, o aluno pode problematizar o mundo em que vive, construindo conhecimento ao reconhecer os limites, as semelhanças e diferenças entre duas tipologias de república. Desse modo, os riscos de anacronismo no ensino de história no Ensino Médio seriam minimizados.

Nas relações entre a construção do conhecimento histórico e o anacronismo, Nicole Loraux defende que o historiador deve assumir o risco de ser anacrônico e tentar, ao máximo, identificá-lo a ponto de minimizá-lo, reconhecê-lo e controlá-lo para que ele não invalide sua produção historiográfica. Evitá-lo completamente seria, na visão da autora, uma tarefa quase impossível. O presente pode e deve ser a mola propulsora da problemática na qual se baseará o trabalho historiográfico, contudo, ela não deve ser a única mola. Seria necessário, em se tratando de um estudo dos conceitos, a percepção de como os termos eram apreendidos e difundidos por nossos antepassados, a fim de que suas preocupações também formem a rede problemática que permeará as páginas escritas pelo historiador. Nas palavras da própria autora, "É preciso saber ir e vir, e sempre se deslocar para proceder às necessárias distinções" (LORAUX, 1992, p. 64). No caso

\footnotetext{
${ }^{9}$ A sensação de proximidade/conhecimento do alunado em relação à República Romana (e mesmo à história de Roma como um todo) é causada, em grande parte, pela divulgação do tema pela mass media, seja por meio de jogos eletrônicos, filmes ou séries que abordam o cotidiano romano.
} 
do historiador da Antiguidade, esse distanciamento de seu objeto de estudo seria um fator a mais de complexidade na escrita historiográfica, definindo a Antiguidade como um campo profícuo para comparações e analogias indispensáveis à construção do conhecimento. Lançar perguntas do passado para os problemas do presente - e não o contrário, conforme se dedicam os historiadores profundamente influenciados pelo presentismo - diminuiria o peso do anacronismo na produção historiográfica, segundo Loraux (1992, p. 64).

A relação entre conceitos e sociedade também é fundamental na obra de Reinhardt Koselleck. Para ele, não há possibilidade de se explicar uma sociedade sem a utilização/explicação dos conceitos que a permeiam. Para o autor, sem os conceitos comuns não há sociedade. Não se pode pensar, contudo, que um conceito encerra em si mesmo apenas um significado, ou ainda que ele possa ser utilizado por nós com a mesma ideia com a qual foi utilizado no momento de sua formação. Um conceito, para ser visto assim, tem que ter um cunho político-social, ser (por vezes) generalizante e (sempre) polissêmico (KOSELLECK, 2006).

Seguindo na mesma linha de raciocínio, Paul Veyne definiu que conceitos são como invariantes históricos, ou seja, termos utilizados em contextos distintos, sem alterações morfológicas, mas com grande diferenciação em sua semântica. Dessa forma, os invariantes de Veyne permitem analisar as peculiaridades dos fatos históricos, que não deixam de apresentar sua faceta singular mesmo que definidos por termos que, à primeira vista, são generalizantes (VEYNE, 1983). Sem a apresentação conceitual, tornar-se-ia impossível realizar a explicação histórica, uma vez que os fatos existem apenas em termos abstratos, sendo necessária sua conceituação para o seu entendimento. Assim como para Koselleck, para Veyne a relação entre conceitos, fatos e teoria política e social é fundamental para a construção da ciência histórica (VEYNE, 1983).

Um conceito seria para Veyne, portanto, a constante que permitiria o historiador trabalhar diferentes contextos históricos ao longo do tempo. Tal constante, contudo, seria acompanhada de variáveis que permitiriam especificar a respeito de qual imperialismo, e.g., dentre tantos que existiram, aquele historiador faz referência.

No que tange ao ensino da história de Roma, a utilização do termo imperialismo, principalmente nos livros didáticos, deveria vir acompanhada das características específicas daquele processo histórico, como sua longa duração, a variedade de ações romanas para conquistar um território, as diferenças entre os processos de conquista no Oriente e no Ocidente e as múltiplas tipologias de resistência à conquista romana. Desse modo, o imperialismo não seria visto como um processo natural, mas sim uma construção humana. Estabelecido esse processo, o conceito de imperialismo ganharia profundidade histórica, uma vez que seria alocado temporalmente, o que propiciaria a diferenciação entre o imperialismo romano e o imperialismo britânico moderno, por exemplo. A utilização dos conceitos, invariantes pela natureza científica de sua produção, e suas variáveis temporais, permitem externar o peso de sua época na sua elaboração. Em outras palavras, as conquistas territoriais romanas, as quais, grosso modo, damos o nome de imperialismo romano, apresentavam, à época, um significado totalmente distinto do que entendemos como o imperialismo moderno britânico. Os conceitos, portanto, permitem que o historiador realize seu trabalho de generalizar (a partir do conceito de imperialismo, trans-histórico) especificando (o imperialismo romano). Nas palavras do próprio Veyne: “ora, o que é uma ciência, senão a determinação de constantes que permitem reconhecer a diversidade dos fenômenos?" (VEYNE, 1983 p. 8).

Tendo em vista as contribuições explicitadas acima, é relevante observar se o conceito de religião romana é minimamente trabalhado pelos livros didáticos, ou seja, se ao menos ele é explicado, ou se é apresentado o que a religião significava para os romanos. Uma breve explicação do que seria a religião para os romanos afastaria os alunos do anacronismo. Não obstante, também apresentaria ao estudante, ainda que brevemente, que a concepção atual de história não consiste apenas em narrar um acontecimento ou descrever uma ação, mas sim 
explicá-los, conceituá-los, problematizá-los e mostrar suas variadas possibilidades de interpretações. Por fim, não seria exagero dizer que permitiria ao aluno ter contato com uma alteridade religiosa que abriria caminho para a percepção das diversas religiões presentes no mundo contemporâneo.

\section{RELIGIÃO ROMANA: OBSERVAÇÕES PRELIMINARES}

Um ponto crucial para a discussão de religiões em salas de aula e em livros didáticos seria a percepção de que se trata de um tema cuja abordagem historiográfica é justamente oposta à abordagem religiosa. Em outras palavras, a religião deve ser vista como parte de uma sociedade, e não como algo externo a ela, criada de forma sobre-humana. Tal vertente é representada por ícones do estudo de religiões, como William Paden (1992). ${ }^{10}$

Neste momento, entra em cena uma discussão tradicional sobre a Antiguidade nos livros didáticos nacionais. ${ }^{11}$ Ela versa a respeito do reduzido número de especialistas e da dificuldade dos professores em se atualizar a respeito da produção internacional e, por vezes, serviu como pretexto para sua baixa qualidade. Contudo, com o avanço das pesquisas nacionais e os intercâmbios acadêmicos realizados, tal argumento não é mais válido. Utilizo aqui um artigo nacional que, a partir da relação estabelecida

\footnotetext{
${ }^{10} \mathrm{~A}$ ideia de que a religião é uma construção social é muito bem trabalhada por Paden (1992), para quem a história da religião pode ser lida como a história dos objetos feitos sagrados por determinados grupamentos humanos. Em outras palavras, fica estabelecido um vínculo entre uma sociedade e sua religião, ou religiões, que impede a construção de um imaginário popular que as defina como algo natural, sobre-humano e previamente criado.

11 José Otávio Guimarães acusou os livros didáticos de, até pouco tempo atrás, utilizarem manuais historiográficos escritos em fins do século XIX e início do XX como base para a apresentação de seus temas. Uma realidade que desde os anos 2000, com o avanço da internet, não mais se justifica, tendo em vista a facilidade para o acesso à novas fontes de documentos e bibliografia. Os estudos a respeito de religiões clássicas, e ele utiliza como exemplo a religião grega, seriam um instrumento para se criticar e dialogar com a nossa própria sociedade (GUIMARÃES, 2008, p. 10-13).
}

entre sociedade e construção da religião apresenta as características básicas da religião romana. Refiro-me ao artigo "A Religião na Urbs", escrito por Claudia Beltrão e disponível em uma coletânea escrita em português voltada para o grande público intitulada "Repensando o Império Romano", organizada por Norma Musco Mendes e Gilvan Ventura (2006).

Um dos temas tratados por Beltrão versa sobre os limites do estudo da religião romana, que pode estar repleto de elementos a respeito dos quais temos pouco ou nenhum registro. Quando as fontes sobreviveram ao peso dos séculos, permitiram principalmente um estudo das práticas religiosas da elite e dos cultos públicos, e pouco nos permitem vislumbrar a religião privada e das massas, apontando para a questão: não seria mais correto falar em religiões romanas? Por fim, recorro à relevância dada aos rituais, que seriam os elementos mais bem documentados ao longo da história romana e, por isso, imprescindíveis para uma definição da religião romana (BELTRÃO, 2006, p. 137-138).

A compreensão de outros elementos da religião romana, contudo, permitiria uma definição mais segura a respeito deste tema. Um desses elementos é a relação entre os deuses e os homens que, segundo a autora, é digna de poucos registros literários, apesar de estar presente no cotidiano das pessoas e nos assuntos do Estado, nas seguintes formas: interpretação de auspícios; prodígios; declarações de guerra; celebrações triunfais; festivais; fundações de templos; eleições; assembleias; nos jogos etc. (BELTRÃO, 2006, p.139).

Se no mundo contemporâneo ocidental o Estado, desde a Revolução Francesa, tem firmado posição em sua laicidade, na Antiguidade Romana a realidade era distinta, uma vez que a guerra e a paz, por exemplo, conforme indicado acima, eram assuntos religiosos. Disso, depreende-se o quão imiscuídas estavam política e religião, o que configuraria um bom ponto de partida de discussão em sala de aula, tendo em vista que aborda um problema antigo, mas que ganha contornos contemporâneos passíveis de serem discutidos por jovens do Ensino Médio. Nos últimos anos, as questões de gênero, 
as lutas pelos direitos civis das comunidades LGBT e as relações estabelecidas entre grupos políticos e lideranças religiosas têm levado a uma discussão profícua a respeito dos limites estabelecidos entre os campos religiosos e políticos. Nosso alunado não está fora desse contexto, não sendo, portanto, essa tipologia de discussão algo desconhecido para ele.

Outro ponto que merece destaque e esboçaria uma fértil discussão em sala de aula é o respeito à alteridade religiosa. Para Claudia Beltrão (2006. pp. 146-152), tradição e inovação andavam lado a lado, pois assim como respeitava e absorvia novos cultos, a religião romana buscava manter as tradições do mos maiorum. ${ }^{12}$

A partir das características apresentadas por Beltrão, indica-se que, enquanto um conceito, a religião romana poderia ser definida como: uma forma de construir um mundo, com um sistema de linguagens, práticas e rituais que o organizam em um determinado espaço e tempo. Percebe-se, assim, a íntima relação entre sociedade e religião. Em um mundo que convive com casos cada vez mais explícitos de intolerância religiosa, a percepção da religião enquanto mais uma construção social, como diversas outras, seria importante para que o aluno pudesse buscar os meios de se elaborar uma sociedade que respeite as diferenças religiosas, conforme conjecturam os instrumentos normativos que regem a educação nacional. Portanto, ressalta-se a importância em se analisar uma manifestação cultural de outra temporalidade histórica dentro de seus contextos de produção, conforme defende a legislação educacional, como pode ser visto abaixo:

Situar as diversas produções da cultura - as linguagens, as artes, a filosofia, a religião, as ciências, as tecnologias e outras manifestações

\footnotetext{
${ }^{12}$ Considerado como o costume dos ancestrais, o mos maiorum era a origem das normas sociais estabelecidas pelos romanos, sendo, por isso, considerado o pilar da tradição romana. Disponível em: http://referenceworks.brillonline.com/search?s. $\mathrm{q}=\operatorname{Mos}+$ maiorum\&s.f.s 2 parent $=\&$ search- go $_{0}=$ Search Acesso em: 15 set. 2016
}

sociais - nos contextos históricos de sua constituição e significação. (BRASIL, PCNEM, 2000. p. 28)

Ao relacionar a legislação educacional brasileira com as teorias sobre o uso de conceitos em história e a relação entre sociedade e religião, erigem-se as seguintes problemáticas que nortearão o estudo de caso aqui feito: há a preocupação em evidenciar o que era a religião romana para os romanos? Ou, mesmo, haveria o cuidado de apresentar a religião romana como plural? Quais características da religião romana são identificáveis nos livros didáticos? Quais anacronismos são vistos? Eles invalidam, prejudicam ou mascaram a construção do conhecimento? O conceito de religião é temporalmente estabelecido, ou seja, estabelece-se a perspectiva histórica que separa a religião romana da ideia de religião na contemporaneidade? De que forma a religião romana pode nos ajudar a discutir a intolerância religiosa da atualidade?

São estas as perguntas feitas aos exemplares recolhidos que, a partir deste momento, serão analisados.

\section{ESTUDOS DE CASO: A RELIGIÃO ROMANA EM LIVROS DIDÁTICOS DO PNLEM}

O Plano Nacional do Livro Didático para o Ensino Médio (PNLEM) é um instrumento criado pelo governo para chancelar os livros didáticos que estejam de acordo com os instrumentos normativos que regem a educação nacional, como a Constituição Federal de 1988, a Lei de Diretrizes e Bases da Educação Nacional, os Parâmetros Curriculares Nacionais e as Orientações Curriculares Nacionais. Além dessa face legal, o PNLEM ${ }^{13}$ analisa as metodologias empregadas na confecção dos livros, a pertinência científico-acadêmica das obras voltadas

\footnotetext{
${ }^{13}$ O PNLEM apresenta uma periodicidade trienal, sendo seu último exemplar o de 2015. O próximo será lançado em 2018. Nesse intervalo os livros aprovados pelo PNLEM recebem a chancela do governo federal.
} 
para o público escolar e os objetivos que as obras traçam para o ensino de história. Desse modo, apesar de preocupado com a construção de uma educação crítica e cidadã, o PNLEM também demonstra ser um discurso produzido pelo Estado, que o utiliza como instrumento de poder.

Na relação entre a academia e o livro didático, o foco não deve recair sobre a profundidade ou obrigatoriedade de um determinado tema. Não se trata de exigir que um livro didático tenha o cuidado de discutir a religião romana exatamente como acadêmicos o fazem, mas sim de buscar entender a lógica de sua produção, suas vinculações teóricas e a forma como representa a religião romana. Ressalto que concordo com as ideias de Ana Teresa Marques e Gilvan Ventura, para quem o livro didático é, além de uma mercadoria de grande valor no mercado editorial, depositário do conhecimento que será fonte de consulta de alunos e professores e um elemento complexo que carrega em si um discurso, que precisa ser analisado de acordo com sua época de produção (2008, p. 23). Portanto, sua análise torna-se necessária, dentro da lógica deste artigo, para entender quais visões de mundo são associadas à religião romana.

Foram escolhidos três exemplares de grande circulação nas escolas do Rio de Janeiro, produzidos dentro da última década e que constam no PNLEM. Além do fato de terem constado no PNLEM, os livros tem características distintas que são relevantes para sua escolha. O livro escrito por Gilberto Cotrim, por exemplo, merece destaque, pois se encontra no mercado editorial há décadas, sendo, por isso, um discurso que alcançou uma grande abrangência na educação nacional. Já o livro de Patrícia Braick e Myriam Mota, que também consta no PNLEM, apresenta uma proposta de ensino de história que integra as páginas dos livros com um conteúdo digital amplo que, na teoria, atrelaria o conhecimento discutido nas páginas com a vida atual dos alunos. Por fim, foi escolhido um livro organizado por uma série de autores com profunda ligação com o meio acadêmico (Ronaldo Vainfas, Sheila de Castro Faria,
Jorge Ferreira e Georgina dos Santos), o que poderia desvendar uma grande preocupação desses autores em fazer a ponte entre a academia e a sala de aula.

Caso 1: "História: volume único". (VAINFAS, Ronaldo; FERREIRA, Jorge; FARIA, Sheila; DOS SANTOS, Georgina. História: Volume Único. 2 Ed. São Paulo: Saraiva, 2014)

A parte de religião romana encontra-se no capítulo 5, intitulado Mundo Romano, e que se estende por 21 páginas (da página 58 até a 79). Neste caso, assim como nos demais exemplares aqui analisados, este capítulo seria dedicado aos alunos do primeiro ano do Ensino Médio. Atualmente é comum identificar duas propostas de currículo nas escolas do Rio de Janeiro. A primeira delas visa a trabalhar todo o currículo de História ao longo dos sete anos que englobam o segundo segmento do Ensino Fundamental e o Ensino Médio. Outra corrente buscar trabalhar o conteúdo de história no Ensino Fundamental e retomar as discussões, de forma mais profunda, no Ensino Médio. Dentro da primeira vertente, portanto, o conteúdo de História Antiga, e especificamente o de Roma, seria trabalhado com alunos do primeiro ano do Ensino Médio. Em escolas que seguem o segundo modelo de currículo, não se trabalha História Antiga no Ensino Médio.

O primeiro destaque do capítulo seria o próprio título. Não se trata de Roma, a cidade, tampouco do Império, mas sim de todo um Mundo, apontando para uma noção de universalidade da cultura romana pelo Mediterrâneo Antigo. Chama a atenção o fato de, na primeira página, haver um box ${ }^{14}$ logo abaixo do título do capítulo no qual os autores fazem menção ao surgimento de Jesus dentro do Império Romano (p. 58). Antes mesmo de apresentarem o que chamam de Mundo Romano, eles partem de uma religião monoteísta predominante no Brasil para iniciar a discussão sobre os romanos,

\footnotetext{
${ }^{14}$ Um box geralmente é utilizado pelos autores para consolidar uma informação dada no corpo do texto ou para explicar um termo que pode ser de difícil entendimento para o aluno. Não raramente, um box também atua como uma ferramenta de apresentação de um tema que, apesar de relevante, não foi trabalhado no corpo do texto.
} 
cuja principal marca religiosa foi o politeísmo. 0 peso do presente também é identificado na imagem de apresentação de Roma, uma cena do filme Gladiador, ${ }^{15}$ do já distante ano 2000. A representação inicial de Roma é feita sem qualquer preocupação em se discutir a imagem que é passada pelo filme. A Roma Antiga é apresentada ao alunado sob a ótica típica dos produtos dos mass media, que a representam como uma fonte de poder, fazendo uma associação entre esse poder e toda a ferocidade que envolve a imagem moderna dos gladiadores romanos. Contudo, esta tipologia de representação deveria, ao menos, ser questionada nas páginas de um livro didático, o que não acontece no livro analisado. Dessa forma, a imagem apresentada serve apenas como uma mera ilustração que cria, no limite, uma imagem de Roma intrinsecamente ligada à violência dos jogos gladiatórios.

A primeira menção a um aspecto da religião romana é a definição do pater familias enquanto chefe sacerdotal de sua família. Trata-se, no entanto, de um comentário extremamente simplório, como podemos ver a seguir: "Por também acumular a função de sacerdote do grupo familiar, era responsável pelo culto dos antepassados" (p. 61). Nesta apresentação, perde-se a chance de se indicar o caráter plural da religião romana, uma vez que não há a demonstração de que havia distinções entre a religião pública e a privada, sendo esta última extremamente diversa em suas práticas.

Na mesma página, mais uma vez, há um box com uma mera indicação de uma festa relacionada à religiosidade romana, conforme podemos ver abaixo:

No mês de janeiro de cada ano, os romanos realizavam, nos cemitérios, as parentálias, verdadeiros festins para celebrar a memória de seus parentes falecidos. Em cada epitáfio era comum registrar um breve histórico do morto, informações sobre seu clã e a maneira como

${ }^{15}$ GLADIATOR. Direção: Ridley Scott. Produção: Douglas Wick, David Franzoni, Branko Lustig. Intérpretes: Russel Crowe; Joaquim Phoenix e outros. Roteiro: David Franzioni Música: Hans Zimmer; Lisa Gerrard. Los Angeles: Universal Pictures, 2000. 1 DVD (155 min). viveu sua vida; ao final usava-se a expressão: ‘ Hic situs est. Sit tibi terra levis' (Aqui jaz, que a terra te seja leve). No cemitério de sua cidade há expressões latinas em lápides? Elas aparecem em muitos túmulos? Por quê? (VAINFAS; et al., 2014, p. 61)

Na passagem acima, parte-se de uma pretensa semelhança entre os túmulos romanos e os atuais, cuja possibilidade de ter epitáfios em língua latina advém mais da tradição católica luso-brasileira do que de uma influência romana. Há um salto no tempo que desconsidera outras influências que não as romanas e aloca o latim como uma herança direta e ininterrupta dos romanos, levando a uma ideia equivocada de proximidade com a Antiguidade que não se justifica.

Em um terceiro box, intitulado "Outra dimensão: Cultura" (p. 62), a partir de vestígios arqueológicos do Capitólio, os autores indicam que naquele monte foi erguido um templo em homenagem aos três principais deuses romanos: Júpiter, Juno e Minerva. É a primeira vez que o termo "religião romana" aparece, ainda que de forma indefinida, sendo apontado seu caráter sincrético, pois indica a carga de influência etrusca sobre a religião romana.

Até o momento, percebe-se que a religião romana sequer foi trabalhada, ou definida enquanto um conceito. Ela não passaria de um detalhe na vida dos romanos e parece estar fora de seu cotidiano. Nenhuma das características básicas da religiosidade romana foi apresentada, como os festivais, os ritos e os auspícios. Mesmo em uma tipologia de história que beneficia a política, seria muito importante a apresentação da relevância dos auspícios para o cotidiano político de Roma. Pautar todo um ensino de Roma com base em sua história política e não estabelecer a íntima relação entre religião e política é contraditório e anacrônico, tendo em vista que se aplica a moderna visão de separação entre esses dois campos para um período na qual ela não existia.

O espaço dedicado à religião romana é ainda desvalorizado se comparado ao destaque dado ao cristianismo. Foram três boxes que comentaram aspectos da religiosidade romana, e não da própria 
religião em si ou do conceito de religião. Tendo em mente que um box é uma parte complementar de um texto, percebe-se o caráter de supérfluo da religião romana no livro didático analisado. Podese entender esta lógica em um livro que privilegie a política romana. Seria, portanto, uma questão de recorte de escolha do campo histórico com o qual os autores definiram sua linha de escrita. Contudo, ao se analisar o espaço dado ao cristianismo percebe-se que não se tratou de uma escrita voltada apenas para a política.

Enquanto a religião romana sequer é definida, o capítulo dedica mais de uma página inteira ao cristianismo em um tópico intitulado: "O cristianismo: de Jesus aos mártires" (p. 70). Ao contrário do politeísmo, relegado a um box, o cristianismo faz parte da divisão do capítulo, sendo o tema do item número quatro, o penúltimo do texto sobre o Mundo Romano. Para um leitor mais inexperiente, como nosso aluno do Ensino Médio, esta divisão de capítulo pode levar à conclusão de que o cristianismo surge dentro de um vácuo religioso existente no Império Romano.

Além disso, o texto apresenta o martírio como um tema preponderante do cristianismo, quando na verdade trata-se de uma temática secundária. Os mártires são destacados em dois momentos: no título do tópico 4, "Cristianismo: de Jesus aos mártires" (p.70); e no box do fim do tópico, "Gladiadores, feras e mártires na Roma Imperial" (p. 71). Seguindo nesse caminho de desvalorização da religião romana e valorização do cristianismo, os jogos gladiatórios são simplesmente retirados de seu contexto religioso de fundação, pois teriam surgido como um elemento do programa ritual de ritos funerários em homenagens aos antepassados, e passam a ser representados como a imagem do gladiador de Russel Crowe (p. 58), um exemplo de força, ferocidade e poder que marcaram a Roma Antiga (GARRAFONI, 2005)

A associação direta entre gladiatura e mártires cristãos remete a uma generalização abusiva que distorce o ensino deste tema. Ela é fruto de uma invectiva cristã de história que já foi profundamente debatida e criticada na historiografia. As chamadas "perseguições" romanas não foram sofridas exclusivamente pelos cristãos. Não se nega a existência de repressões religiosas romanas, ainda que pontuais, contudo, tais ações, da forma como são apresentadas no livro didático, parecem criar a imagem de que os cristãos foram os alvos escolhidos pelos romanos para serem jogados às feras indiscriminadamente, sem se levar em conto o contexto político-religioso da época. Dessa forma, acaba por ser descartada uma das principais características da religião romana, sua receptividade a novas práticas religiosas.

O conceito de religião romana, portanto, não é trabalhado nesta obra, e qualquer outra característica além do politeísmo não é sequer citada. O livro praticamente silencia-se a respeito da religião romana, que pode ser entendida pelos alunos como algo secundário ou de menor relevância para os romanos. Percebe-se que esta configuração de discussão sobre a religião romana não é um simples reducionismo, que muitas vezes é necessário para a discussão historiográfica em nível escolar, mas sim uma grave distorção da religião romana.

Caso 2: "História: das cavernas ao terceiro milênio" (BRAICK, Patrícia Ramos \& MOTA, Myriam Becho. História: das cavernas ao terceiro milênio. $4 \mathrm{Ed}$. São Paulo: Moderna, 2012.)

O livro dedica dezenove páginas ao estudo de Roma em um único capítulo intitulado "O esplendor de Roma" (p. 97-116). A primeira parte (p. 98) dedica-se à demonstração da atualidade do estudo de Roma, tendo em vista que ela seria, nas palavras das autoras: "a gênese de nossa própria sociedade" (p.98). Esta afirmação viria, em parte, devido ao peso de Roma na construção do mundo contemporâneo, conforme pode ser visto na afirmação: "Afinal, foi em Roma que se desenvolveu o latim, língua da qual derivam muitos dos idiomas modernos, o regime republicano, o direito e outros elementos ainda presentes no mundo contemporâneo" (p. 98). Na forma como é apresentado, parece que os elementos jurídicos, políticos e culturais citados pelas autoras ainda estão em voga no século XXI com 
as mesmas características antigas. Parte-se de apresentações conceituais típicas do contexto romano, mas que foram profundamente alteradas ao longo dos anos, sendo muitas vezes inteiramente distintas de seus significados originais. A República Romana, por exemplo, não está mais presente no mundo contemporâneo. Isso é totalmente diferente de afirmar que a ideia de república foi criada em Roma e difundida, alterada e aperfeiçoada ao longo dos tempos até sua aplicação nos dias de hoje.

O cenário construído acima, ainda que em poucas palavras, produz uma sensação de proximidade do aluno com o cotidiano romano, uma vez que traça de forma linear o caminho percorrido pela herança cultural romana desde a Antiguidade até a Contemporaneidade. Essa ideia de proximidade da atualidade com a Roma Antiga já foi amplamente discutida e criticada por Lynette Mitchell (2011), Mary Beard e John Henderson (1998) e Simon Goldhill (2007), dentre outros, em obras que indicam que seria relevante para o estudo da Antiguidade buscar estabelecer suas diferenças, e não apenas suas semelhanças com o mundo atual, tendo em vista o caminho tortuoso que os elementos culturais antigos percorreram até a atualidade. Ao privilegiar as continuidades e relegar as diferenças a um segundo plano, as autoras contradizem os próprios PCN`s, segundo os quais seria indispensável para a história: "Estabelecer relações entre continuidade/ permanência e ruptura/transformação nos processos históricos" (BRASIL, PCNEM, 2000, p. 28)

A segunda seção de destaque do capítulo que merece análise intitula-se "A força do poder espiritual" (p. 107). Destaco duas características desse título. Em primeiro lugar, ele parte de uma questão meta-histórica e etérea, a espiritualidade, para se referir a uma religião que, conforme foi visto acima, deve ser entendida como uma construção social. Em segundo lugar, em momento algum há a indicação de qual religião as autoras apresentariam. Tendo como base a ideia de que a religião romana oficial foi por séculos politeísta e que o capítulo versa sobre Roma, subentende-se que ele seria o foco do tópico, o que não ocorre, uma vez que o trecho dedica-se ao cristianismo. Mais uma vez, o silêncio a respeito do politeísmo romano faz-se presente.
Em um capítulo dedicado principalmente aos acontecimentos políticos dos romanos, o silêncio a respeito das relações da religião oficial com os cargos republicanos é ensurdecedor para os especialistas em Antiguidade. Não obstante, fica difícil compreender como se valoriza a imagem de Augusto sem explicar os motivos de sua divinização. Segundo as autoras, "com esse título [de Augusto] o imperador passou a ser cultuado como um deus" (p. 105). Quais seriam os motivos da elevação de Augusto à categoria de deus? Isso teria ocorrido antes ou depois da morte dele? De que forma este título conferia a ele poderes políticos e/ou religiosos? Essas seriam perguntas que poderiam desenvolver melhor a relação da política com a religião no principado de Augusto.

O tópico termina com a perseguição sofrida pelos cristãos até o Édito de Milão de 313 , feito pelo imperador Constantino e que definiu a liberdade de culto aos romanos. Mesmo nesse ponto, o interesse dos cristãos sobrepõe-se aos dos demais grupos religiosos, tendo em vista que o referido édito concedeu liberdade de culto a todos os romanos, e não apenas aos cristãos, conforme está especificado no livro (p. 107). Ignorar que havia outras comunidades religiosas dentro do Império, e que estas também foram agraciadas com a publicação do referido édito, distorce o ensino de história a ponto de criar uma visão que concentra toda a religião do Império Romano ao redor dos cristãos. Ao abordar o tema com o foco sobre o cristianismo e sua luta para suplantar o politeísmo, o texto nega a possibilidade de um ensino de história que supere "visões redutoras e segmentadas de mundo", conforme pretende o próprio Guia do PNLD (2014, p.17). Ir além de uma visão redutora e maniqueísta de mundo seria fundamental para que o alunado pudesse compreender e criticar o mundo atual em toda sua complexidade.

Após o fim das páginas sobre a história política de Roma, surgem duas páginas a respeito da cultura e do cotidiano romano (p. 108-109). Esta divisão aponta para uma visão de mundo que separa as esferas políticas, culturais e religiosas dos romanos, o que simplesmente mostra-se inadequada para o estudo da sociedade romana. Os temas trabalhados 
nesta subdivisão do capítulo estão ordenados após a seção que trata da "Queda de Roma" (p. 107). Tal divisão passa a uma ideia de que aspectos como a religião e a literatura não estavam interligados aos acontecimentos políticos romanos. A primeira frase deste segmento do livro é digna de comentário: "a cultura romana recebeu contribuições dos mais diversos povos" (p.108). A partir deste momento as autoras demonstram como a religião romana recebeu influências de outros povos, como os etruscos. O que questiono neste tipo de apresentação sobre a religião romana é justamente o fato de esses argumentos terem sido totalmente ignorados ao longo das páginas anteriores. Se a cultura (incluindo nela a religião) romana era receptiva a novos elementos culturais, o que fez os romanos perseguirem outras religiões? Se havia esta miscigenação cultural, por que ela não foi destacada quando o livrou tratou a respeito das invasões germânicas (p.107)? Essas invasões não teriam transformado o Império em termos culturais? Tais assuntos não deveriam ser compartimentados, tendo em vista que tinham profunda ligação com o cotidiano político romano, que era o foco do livro.

Necessário ressaltar que houve, ao menos, a indicação de que a religião romana foi construída socialmente e de forma processual, o que enriquece o debate com o alunado e impede que ele veja religiões como algo sobrenatural e previamente existente à presença humana no mundo. Outro ponto positivo na apresentação da religião romana é a correta atribuição dos jogos de gladiadores a cerimônias fúnebres religiosas em homenagem aos antepassados. Isso demonstra que tais ritos se desgarraram de seus aspectos religiosos para serem difundidos pelo império com um novo significado que pouca relação guardava com seu sentido original. $O$ trecho em questão é bastante elucidativo e tem grande relevância para evidenciar que a imagem difundida sobre a gladiatura no mundo contemporâneo não tem relação com sua criação, conforme podemos ver abaixo:

Os combates de gladiadores tinham, inicialmente, uma função religiosa. [...] Com o passar do tempo, esses acontecimentos foram perdendo seu vínculo com a religião e se transformaram em espetáculos públicos patrocinados pelos imperadores ou por representantes da nobreza (BRAICK \& MOTA, 2012, p. 109).

Apesar de trabalhar a relação entre jogos gladiatórios e religião, em momento algum o texto trata a religião romana como um conceito que precisa ser alocado em seu contexto de produção. Dessa forma, o livro assemelha-se às demais obras aqui analisadas, pois ignora qualquer tentativa de definição a respeito do que seria a religião romana.

O livro ainda apresenta ao aluno o calendário romano sem, contudo, fazer qualquer menção de sua íntima relação com a religião romana e as eleições, relegando ao segundo plano as características básicas desse instrumento de marcação do tempo. A apresentação do calendário romano tenta demonstrar sua íntima relação com o calendário atual, conforme pode ser visto abaixo:

Um exemplo da presença romana na sociedade atual pode ser notado na contagem do tempo. [...] Além disso, César reajustou o calendário com bases em pesquisas astronômicas e dividiu o ano em 12 meses, correspondentes a 365 dias e 6 horas. Era o calendário Juliano, modificado somente em 1582 pelo papa Gregório XIII (p. 108)

No trecho acima, o livro parte da ideia de que o calendário juliano é ainda muito próximo do calendário atual, ou seja, demonstra a permanência cultural da sociedade romana nos dias de hoje. Contudo, o trecho deixa de evidenciar a profunda ligação dos calendários com a estrutura religiosa romana, uma vez que omite a informação de que Júlio César somente teve poder para realizar esta mudança porque era o Pontifex Maximus da religião romana. Não era seu poder político que o credenciava a realizar a consecução de um novo calendário, mas sim seu poder religioso. Estas relações permitiriam desvelar uma íntima relação entre aspectos que hoje são tratados como distintos entre si.

Em uma percepção geral do capítulo, não há a definição do que se tratava a religião romana, que tampouco é vista como um conceito, assim como não são estabelecidas discussões que permitam 
discutir a tolerância religiosa, uma vez que a religião romana absorveu aspectos de diversos povos. Pelo contrário, ressalta-se a perseguição sofrida pelos cristãos, sem ao menos contextualizar os motivos do cristianismo ser perseguido, assim como não se comenta o fato de que o cristianismo não foi a única religião a sofrer sanções legais, ignorando a multiplicidade de um Império que se estendia por todo o Mediterrâneo antigo.

\section{Caso 3: "História Global: Brasil e Geral" (COTRIM, Gilberto. História Global: Brasil e Geral. 9 Ed. São Paulo: Saraiva, 2008.)}

O terceiro livro dessa análise parte da atualidade de elementos culturais romanos como: o latim, o direito, a arquitetura e as instituições jurídicas e políticas. Mais uma vez, é estabelecida uma ponte direta entre o passado e o presente, sem sequer pensar em suas idas e vindas, conforme já foi amplamente discutido neste artigo até o momento.

A seção concernente à religião romana recebe um título específico, "Do politeísmo ao Deus Único cristão", e se estende por duas páginas (p. 99-100) do capítulo 9 (p. 90-103). Em uma observação preliminar, percebe-se que o politeísmo é definido por letras iniciais inteiramente minúsculas, enquanto que o "Deus Único" recebe letras iniciais maiúsculas, o que seria desnecessário, tendo em vista que o título parece destacar que o cristianismo tem um deus apenas, em contraposição ao politeísmo. Esse deus cristão seria mais um deus dentre outros tantos dentro do ambiente romano e não justificaria a utilização da letra maiúscula, pois não estaria especificando seu nome. Além disso, não há justificativa plausível para a palavra "único" vir com a primeira letra maiúscula. Essa sentença, portanto, acompanha a lógica de uma seção do livro feita para engrandecer o cristianismo e diminuir o politeísmo no cotidiano romano.

Além da questão das letras utilizadas no título, percebo no trecho (p. 99) uma seta temporal que caminha a partir do politeísmo em direção ao monoteísmo judaico-cristão, indicando uma evolução que levou os romanos a adotarem o cristianismo após terem tido sua fase politeísta. Essa perspectiva religiosa já foi abandonada por antropólogos e historiadores, que a consideram ultrapassada e digna de uma visão de mundo típica do crepúsculo do século XIX e do alvorecer do XX (BELTRÃO, 2006, p. 140). Nessa visão, Roma passaria por estágios de desenvolvimento de sua religião até alcançar a fase cristã, que seria o ápice do desenvolvimento religioso monoteísta.

Mesmo nesse cenário, há aspectos da religião romana que são trabalhados conceitualmente, como o termo politeísmo. Contudo, esta definição reduz o politeísmo romano a uma mera cópia do politeísmo grego, como pode ser visto quando o autor coloca lado a lado os deuses romanos e seus equivalentes gregos (p. 100). Essa ação de reduzir o politeísmo romano a uma adaptação do politeísmo grego representa uma desconsideração em relação à identidade cultural dos romanos e uma visão historiográfica helenocêntrica já superada. Não se nega a influência cultural de povos contemporâneos aos romanos, contudo isto não significa dizer, como pretende o quadro comparativo aqui citado, que deuses gregos receberam outro nome romano e foram adorados pelos mesmos motivos na Grécia ${ }^{16} \mathrm{e}$ em Roma. Ela ocorre justamente em um instrumento, o livro didático, que deveria prezar pela valorização cultural de outros povos para que o aluno possa perceber que culturas são construídas socialmente e reconhecidas por sua identidade.

Apesar dessas associações, este é o exemplar no qual identifico a maior variedade de características básicas da religião romana. Há a preocupação em definir o caráter público da religião romana e indicar uma pluralidade de religiões no Império Romano, diferenciando a religião pública da religião privada (extremamente plural). No entanto, à religião popular associa práticas chamadas de magia

\footnotetext{
${ }^{16}$ Necessário dizer que o livro ignora que as cidades-estados gregas adoravam seus deuses cada uma a sua maneira, havendo, inclusive, uma variação nos nomes de cada deus nas cidades que prestavam seu culto.
} 
e proteção sobrenatural (p. 99), como se isso não fosse uma característica básica de grande parte das religiões, inclusive as monoteístas. Tal ação apresenta uma visão preconceituosa de sociedade e de religião, pois associa a religião oficial à elite da população e as práticas de magia às ditas "pessoas comuns" (p. 99), conforme pode ser visto abaixo:

Além da religião oficial, seguida predominantemente pelos cidadãos de posição social elevada, havia também as crenças ligadas à religiosidade popular, mantida principalmente pelas pessoas comuns (pobres, escravos), que, por meio de rituais de magia, buscavam a proteção sobrenatural contra os males e a violência do cotidiano. (p. 99)

A divisão estabelecida pelo trecho acima tem um viés econômico que serve para justificar práticas religiosas. Essa metodologia, contudo, não é aplicada quando o autor trabalha o desenvolvimento do cristianismo. Destaca-se, ainda, que o autor ignora o fato de que pouco se sabe a respeito da religiosidade popular romana, tendo em vista que foram deixados escassos registros.

Como se mostrou comum nas obras analisadas, o terceiro exemplar dessa análise também ressalta o cristianismo dentro da parte dedicada à religião romana. O ápice de valorização dos cristãos e desvalorização da religião romana aparece quando ele chama os atos cristãos de resistir às perseguições como um "ato heroico" (p. 100). Divide-se de forma maniqueísta politeístas e cristãos, sendo, no limite, uma divisão entre romanos e cristãos, ignorando-se o fato de que muitos cristãos eram romanos e, sobretudo, desconsiderando as pesquisas e a produção acadêmica sobre as religiões antigas.

A narrativa histórica a respeito da religião romana recebe contornos ainda mais cristãos quando é introduzido o termo "pagão" (p. 100). Em três trechos do livro, é possível perceber a mudança de tom do autor em relação a este termo, cuja primeira aparição destaco abaixo:

A oposição dos cristãos à religião oficial de Roma, aos cultos pagãos tradicionais e ao culto à pessoa do imperador. (p. 100)
No trecho acima, o uso do termo pagão justifica-se pelo fato de ser uma frase que apresenta o ponto de vista dos cristãos, que viam os cultos do politeísmo como pagãos. Esta utilização do termo, nesse caso, torna-se, portanto, adequada.

Como o trecho acima se refere a um termo que pode ser de difícil compreensão para o alunado, o autor teve o cuidado de estabelecer um glossário ao fim da página, que pode ser visto abaixo:

Pagão: nome atribuído pelos cristãos, aos povos não-cristãos, que não eram batizados e, em geral, adoravam vários deuses (politeísmo). (p. 100)

O texto acima faz uma definição simples e de fácil entendimento para o estudante típico do ensino médio, que ainda necessita de auxílio para o entendimento de algumas palavras. O problema na utilização do termo pagão, contudo, surge em sua ultima aparição nesta seção, conforme pode ser visto abaixo:

Em 380, o cristianismo passou a ser considerado a religião do Estado, quando o imperador Teodósio recebeu o batismo cristão. Cerca de uma década depois, os cultos pagãos foram proibidos, e o cristianismo tornou-se, efetivamente, a religião oficial de Roma, promovendo a organização da Igreja Católica, que construiu sua hierarquia tendo como modelo a estrutura administrativa do império (p. 100).

É perceptível, para um leitor mais atento, que autor se coloca como cristão ao definir os cultos politeístas como pagãos. Afinal, ele havia acabado de definir o termo pagão como uma terminologia típica dos cristãos. Portanto, percebe-se todo um olhar baseado na invectiva cristã que desvaloriza o politeísmo e atribui a ele elementos negativos, ao mesmo tempo em que valoriza os elementos da religião cristã.

\section{CONCLUSÕES}

O primeiro objetivo deste artigo foi identificar se os livros analisados apresentam, ainda que minimamente, uma definição do que seria a religião romana, ou seja, se a definem em termos conceituais. 
Nesse caso, os três livros aqui analisados falharam de forma indiscutível, pois sequer se esforçaram em apresentá-la enquanto conceito. Na esteira desse erro, surgem outros, também identificados nas três obras analisadas, como o fato de não problematizarem em momento algum o conceito de religião romana, ficando circunscritos a apresentações reducionistas e extremamente generalizantes. Subentendem que o conceito de religião é algo definido para o aluno e, além disso, que a ideia de religião do século XXI é a mesma da Antiguidade. Assim, toda a discussão a respeito da relevância em se estudar os conceitos históricos dentro de seus contextos de produção esvai-se.

Nesse sentido, impede-se a construção de um conhecimento que leve em consideração as relações entre identidade e alteridade, contrariando a própria legislação educacional citada nestas páginas. Não apenas a percepção da alteridade é negada, como também a própria discussão sobre a tolerância religiosa é tolhida, pois não há o reconhecimento da religião romana enquanto um sistema de crenças e valores construído pelo ser humano e que perdurou por séculos. Caminha-se, portanto, para uma história factual e não problemática.

Recorro a Fernand Braudel (2013, p. 47) quando definiu que a História Antiga seria um dos campos mais adequados para uma produção historiográfica processual, tendo em vista a longevidade das sociedades romanas e grega e a necessária variedade documental para seu estudo. Esse caráter é simplesmente desvalorizado pelos livros aqui analisados.

A respeito das características da religião romana, destaca-se que algumas delas foram identificadas, mas não de forma suficiente para estabelecer um quadro que apontasse aquela soma de características como uma religião. As características que pude observar em pelo menos dois livros foram: os auspícios (Casos 2 e 3), a interação da religião romana com outras regiões (Casos 1, 2 e 3) e o politeísmo (Casos 1, 2 e 3). São poucos elementos em comum, o que mostra o desconhecimento dos autores em definir as características básicas da religião romana.
Além disso, as características que foram apresentadas em momento algum foram vistas como pertencentes a um mesmo sistema de valores e crenças construído socialmente ao longo do tempo.

A percepção da religião romana como uma religião plural tampouco é identificada. Apenas indica-se que havia a religião oficial e a religião privada (Casos 2 e 3), contudo em momento algum isso é explicado ou desenvolvido. Neste ponto, não se trata nem de utilizar conceitos de forma anacrônica, mas sim de deixar nosso alunado em uma escuridão cognitiva, afinal, seria nosso aluno capaz de compreender o que é uma religião oficial e como ela diferencia-se de uma religião privada? Muito provavelmente não, visto que estas tipologias religiosas não são frequentes atualmente.

Não há como deixar de notar, nos três livros analisados, a hipertrofia dos tópicos dedicados ao cristianismo e a redução do próprio politeísmo. Nesta lógica, a religião romana era, no limite, cristã e, assim, o politeísmo aparecia como algo de menor relevância para os romanos. O surgimento do cristianismo, em alguns momentos, é diretamente associado à queda do império, recrudescendo uma corrente historiográfica que remete ao fim do século XVIII. Ainda que o cristianismo possa ser aventado como uma das razões para as transformações políticas e sociais do Império Romano no século $\mathrm{V}$, seu peso nessas transformações já foi devidamente relativizado ao longo das últimas décadas. Assim, não há motivos aparentes para se reproduzir uma corrente historiográfica superada sem abordar novas possibilidades de interpretação a respeito da relação cristianismo e Império Romano. Isso apenas afasta o livro didático da produção acadêmica atual.

Em suma, além do panorama revelado acima, ressalto que os exemplares de livros didáticos aqui analisados não permitem identificar as preocupações que os próprios autores externam em suas falas de apresentação nas obras. Apesar de se preocuparem em fazer os elos com o presente, realizam tais conexões sem considerar devidamente o peso do tempo no significado dos conceitos e, acima de tudo, não desvelam a natureza plural da religião romana, impedindo, dessa forma, que o aluno tenha 
acesso a um mundo religioso mais diverso e aberto à coexistência de variadas formas de religião. O que poderia ser uma ode à diversidade religiosa transforma-se em uma propaganda cristã e sua pretensa luta contra os não-cristãos. Definitivamente, a religião romana ia muito além da dicotomia politeísmo $\mathrm{x}$ cristianismo presente nos livros analisados.

\section{BEYOND THE DICHOTOMY POLYTHEISM $X$ CHRISTIANITY: A CASE STUDY ON ROMAN RELIGION IN BRAZILIAN SCHOOLBOOKS}

\begin{abstract}
Roman religion has been studied in scholarly debates about Antiquity. This is a concept that offers all sorts of interpretation and numerous characteristics. So, this article aims, first of all, to deal with the actuality of the discussion as well as to define some basic features of Roman religion by theoretical discussions that rely on the history of concepts. In a second moment, the aim is to identify if these basic characteristics established by historiography are applied during the production of history's school textbooks.
\end{abstract}

Keywords: Roman religion, Antiquity, Schoolbooks, History of concepts.

\section{REFERÊNCIAS BIBLIOGRÁFICAS}

AUGÉ, Marc. O sentido dos outros. Petrópolis, RJ: Vozes, 1999.

BELTRÃO, Cláudia. A Religião na urbs. In: MENDES, Norma M.; SILVA, Gilvan V. (org.) Repensando o Império Romano. Rio de Janeiro: Mauad X, 2006, p. 137-159.

BELTRÃO, Cláudia. MARQUES, Juliana. B.; TACLA, Adriene. B.; MENDES, Norma. M. A Busca do Antigo. Rio de Janeiro: Nau, 2011.

BEARD, Mary. HENDERSON, John. Antiguidade Clássica: uma brevíssima introdução. Rio de Janeiro: Jorge Zahar Ed., 1998.

BITTENCOURT, Circe. M. F. Ensino de História: fundamentos e métodos. 3ạ Ed. São Paulo: Córtex, 2009.

(org.). 0 saber histórico na sala de aula.

12 ed., 2a Reimpressão. São Paulo: Contexto, 2015.

BRASIL. Ministério da Educação. Secretaria de Educação Media e Tecnológica. Parâmetros curriculares nacionais: Ensino Médio. Brasília: MEC/SEMTEC, 2000.
BRASIL. Ministério da Educação, Secretaria de Educação Básica Guia de livros didáticos. PNLD 2015: História: Ensino Médio. Brasília: MEC, 2014.

BRAUDEL, Fernand. Escritos sobre a história. 3 ed. São Paulo: Perspectiva, 2013.

GARRAFFONI, Renata S. Gladiadores na Roma Antiga: dos combates às paixões cotidianas. São Paulo: Annablume/Fapesp, 2005.

CHEVITARESE, André. L. CORNELLI, Gabriele. SILVA, Maria. A. O. (Org.). A tradição Clássica e o Brasil. Brasília: ARCHAI-UNB/Fortium, 2008.

FUNARI, Pedro. P. A. A importância de uma abordagem critica da história antiga nos livros escolares. In: Revista Historia Hoje, São Paulo, n. 4, 2004.

GOLDHILL, Simon. Amor, sexo e tragédia. Rio de Janeiro: Jorge Zahar Ed., 2007.

GONÇALVES, Ana. T. M. SILVA, Gilvan. V. O Ensino de História nos livros didáticos brasileiros: balanço e perspectivas. In: CHEVITARESE, André. L. CORNELLI, Gabriele. SILVA, Maria. A. O. (Orgs.). A tradição Clássica e o Brasil. Brasília: ARCHAI-UNB/Fortium, 2008, p. 21-34.

GUIMARÃES, José O. Apresentação In: CHEVITARESE, André L. CORNELLI, Gabriele. SILVA, Maria. A. O. (Org.). A tradição Clássica e o Brasil. Brasília: ARCHAI-UNB/Fortium, 2008.

HALL, Stuart. A identidade cultural na pós-modernidade. 5 ed. Rio de Janeiro: DP\&A, 2005.

KOSELLECK, Reinhart. Futuro Passado. Constituição à semântica dos tempos históricos. Rio de Janeiro: Editora PUC-Rio, 2006.

LORAUX, Nicole. Elogio do anacronismo. In: NOVAES, Augusto (Org.) Tempo e história. São Paulo: Companhia das Letras : Secretaria Municipal de Cultura, 1992, p. 5770.

MITCHELL, Lynette. Em busca da Antiguidade. In: BELTRÃO, Claudia. MARQUES, Juliana. B. TACLA, Adriene. B. MENDES, Norma. M. A Busca do Antigo. Rio de Janeiro:Nau, 2011, p. 133-160.

PADEN, W.E. Interpretative Frames/As Society, So Religion. In: _. Interpreting the Sacred. Ways of Viewing Religion. Boston: Beacon Press, 1992, p. 1-14; 28-47.

SILVA, Gilvan. V. Simplificações e Livro Didático: um estudo a partir dos conteúdos de Historia Antiga. In: Hélade, Niterói, Número Especial, 2001, p. 19-24.

VEYNE. Paul. $O$ inventário das diferenças. São Paulo: Brasiliense, 1983. 